\title{
The Influence of Family Support on Providing Complete Primary Immunizations
}

\author{
Ilhami ${ }^{1)}$, Malik Afif ${ }^{2)}$ \\ 1 Department of Health Promotion and Behavior Science, Faculty of Public Health, Universitas \\ Airlangga, Surabaya, Indonesia \\ 2 East Java Provincial Health Office, Surabaya, Indonesia \\ Email: ilhami-2017@fkm.unair.ac.id
}

\begin{abstract}
Background: Primary immunizations is a series of vaccination given to babies before the age of one, and it can actively increase immunity to diseases such as Hepatitis $B$, Poliomyelitis, Tuberculosis, Diphtheria, Pertussis, Tetanus, Pneumonia, and Meningitis caused by Hemophilus influenza type $B$, and measles. Family support is one of the essential factors for the completeness of immunization because it will encourage parents to immunize their children. The social support theory was used here since it assumes that the source of support from families such as parents, siblings, children, relatives, and partners provides examples for individuals to perform or suggest a positive behavior. Objective: This study aimed to determine the effect of family support on the provision of complete primary immunization at the Sidotopo Health Center in Surabaya. Methods: This research used a descriptive-analytic method with a simple random sampling of 54 respondents with a degree of significance $(a=0.05)$. Sample inclusion criteria include mothers who have children aged 12-24 months, have a health card (KMS), and live around the area of Sidotopo Health Centre. The exclusion criteria are those who were not willing to be respondents. Results: The effect of family support on immunization has a significant value of 0.015 ( $P$ Value $<0.05$ ) on emotional support, while the support of appreciation, instrumental support, and informative support are not substantial ( $P$ Value>0.05). Conclusion: Family support for complete primary immunizations includes emotional support, appreciation support, instrumental support, and informative support. Overall, emotional support has a direct influence on providing immunization. Therefore, appreciation support, instrumental support, and informative support did not significantly affect immunization.
\end{abstract}

Keywords: complete primary immunizations, family support, immunization

\section{INTRODUCTION}

In establishing the highest degree of public health, immunization is needed as one of the efforts to prevent the occurrence of a disease. Immunization is an attempt to actively induce or increase a person's immunity to a specific disease so that if one day they are exposed to the disease, they will not get sick or only experience mild symptoms (Kementerian Kesehatan Republik Indonesia, 2018).

Healthy children are the investment and hope for the future of a nation and the successor of future generations. Therefore, the efforts to maintain children's health through primary immunization is essential as stated in the Law of the Republic of Indonesia Number 36 of 2009 concerning
Health (2009): "every child has the right to obtain basic immunization under the provisions to prevent the occurrence of diseases that can be avoided through immunization" (Undang-Undang Republik Indonesia Nomor 36 Tahun 2009 tentang Kesehatan, 2009).

Primary immunizations are consecutive of vaccination given to babies before they reach the age of one-yearold. Primary immunizations can actively increase immunity to diseases, which include Hepatitis B, Poliomyelitis, Tuberculosis, Diphtheria, Pertussis, Tetanus, Pneumonia, and Meningitis caused by Hemophilus influenza type $b$, and measles. A child is declared to have received complete primary immunization if he/she has received one HB-0 immunization, one BCG immunization, 
three DPT-HB/DPT-HB-HiB immunizations, four times polio immunization or three IPV immunizations, and one measles immunization (Ministry of Health, 2018).

In 2017, complete primary immunization in Indonesia reached 91.12\%. This figure is slightly below the 2017 Strategic Plan's target of 92\%. Meanwhile, according to the province, 15 provinces achieved the Strategic Plan target for 2017. One of them is East Java, with the number of complete basic immunization coverage of $96.4 \%$ Kementerian Kesehatan Republik Indonesia, 2018).

The complete primary immunizations coverage in the city of Surabaya in 2018 has exceeded the target with Sidotopo Health Center as the highest $(96.51 \%)$. As one of the WHO priority countries, Indonesia intends to accelerate the achievement of the 100\% $\mathrm{UCl}$ target for villages. The aim is the purpose of immunization in making children immune to diseases that can be prevented by vaccination is realized (Health Office of Surabaya, 2017).

The pros and cons of immunization continue to roll from throughout the years. In 2016, a fatwa from the Indonesian Ulema Council (MUI) explained that immunization is allowed (mubah) as a form of endeavor to establish immunity and prevent the occurrence of a particular disease. Immunizations with haram and/or unclean vaccines are not permitted unless used in an emergency or urgent condition, a halal and sacred vaccine ingredient has not been found yet, and the presence of competent and trusted medical personnel that there is no halal vaccine. However, even though MUI has stated that the immunization law is permissible, there are still people who are reluctant to be immunized (Majelis Ulama Indonesia, 2016).

There are many studies related to immunization that shows the factor of low vaccination. According to the results of previous studies, there is no relationship between the support of health workers with primary immunization status because the role of the workers does not influence the respondent to fully-immunize their children (Dumilah, 2016).

Factors that influence the incompleteness of basic immunization in infants or toddlers are family support, knowledge, and attitudes. The role of the family is significant in making decisions about getting health services. Thus, family support can increase a person's willingness to conduct a complete set of primary immunization (Izza \& Lestari, 2017).

According to previous research on community rejection of complete primary immunization for infants, the research subjects did not provide complete primary immunization to their children due to the lack of support from the environment, including from parents, husbands, and friends. Therefore, there was no encouragement to get immunizations (Sulistiyani, 2017).

Family support is a critical factor for the completeness of immunization because it will encourage parents to immunize their children. Family support such as from parents, in-laws, siblings, and husbands can be achieved by giving attention, empathy, encouragement, advice, and sharing knowledge. Also, the family participates in caring for a child so that it has a significant influence on the decision to give immunizations.

This study used the social support theory, assuming that the source of support from family members such as parents, siblings, children, relatives, and partners provide examples for individuals to perform or suggest a healthy behavior. There are four forms of social support. First, emotional or esteem support, which includes empathy, caring for someone so that it gives a comfortable feeling, attention, and positive acceptance, and gives encouragement to the person being faced. The second is tangible or instrumental support, including assistance given directly or tangibly, as well as people who share or lend money, shop, and care for children. The third is the informational support to provide advice, direction, suggestion, or feedback about how people do things. This support can be done by providing the information needed by the public. The last is companionship support. This type of support is a willingness to spend time with others by giving a feeling of membership in a group of people who are interested in sharing and social activities (Marmot and Wilkinson, 2012).

Family is the most influencing factor affecting immunization status (Rahayuningsih and Khairiah, 2019). It 
indicates that the main factors played a more critical role in a mother's decision to achieve child immunization status. The decision-making process is influenced by family support. The theory of social support is applied for this study to understand the effects of social support on behavior that is not under its control (Rahayuningsih and Khairiah, 2019). Based on the description above, the study was conducted at the Sidotopo Health Centre in Surabaya.

\section{METHODS}

The research was a descriptive study with a quantitative approach. The study only collected primary data obtained from respondents and measured variables at one time. This study was a cross-sectional study, and the data collected at the same time.

The population in this study were all mothers who had babies aged 1-2 years, as many as 200 mothers who lived in the working area of the Sidotopo Health Center in Surabaya. Sample calculation using the Lemeshow formula. The number of samples in this study was 54 respondents. Sampling uses a simple random sampling method, which is a simple random sampling technique. Sample inclusion criteria are mothers who have children aged 12-24 months, have a health card (KMS), and live near the Sidotopo health center. In contrast, the exclusion criteria are not willing to be respondents.

The independent variable in this study is family support, which consists of emotional, appreciation, instrumental, and informative support. The dependent variable is complete primary immunization. Data collection techniques in this study using secondary data and primary data. Secondary data were obtained from the health department and the public health center. Primary data were obtained from a questionnaire that referred to preliminary studies, literature reviews, and KIA documents, after which the data were analyzed univariately and bivariate.

\section{RESULTS AND DISCUSSION}

\section{Characteristics of the Respondents}

Respondent characteristics in this study consisted of age, ethnicity, religion, education, and employment status. Family support can be in the form of emotional support, appreciation support, instrumental support, and informative support-also, the effect of family support on the provision of complete basic immunization.

Table 1. Distribution of Respondents' Characteristic in the Area of Sidotopo Health Centre

\begin{tabular}{lrr}
\hline Characteristics & $\mathbf{n}$ & $\%$ \\
\hline Age (years old) & 2 & 3.7 \\
\hline$<20$ & 36 & 66.7 \\
$21-30$ & 14 & 25.9 \\
$31-40$ & 2 & 3.7 \\
$>41$ & & \\
\hline Ethnicity & 25 & 46.3 \\
\hline Javanese & 29 & 53.7 \\
Madurese & 0 & 0 \\
Arab & 0 & 0 \\
Others & & \\
\hline Religion & 54 & 100 \\
\hline Islam & 0 & 0 \\
Christian & 0 & 0 \\
Catholic & 0 & 0 \\
Budha & 0 & 0 \\
Hindu & & \\
\hline Education & 3 & 5.6 \\
\hline No Education & 11 & 20.4 \\
Elementary & 12 & 22.2 \\
Junior High & 26 & 48.1 \\
High School & 2 & 3.7 \\
University & & \\
\hline Occupation & 49 & 90 \\
\hline Housewife & 3 & 5.6 \\
Employee & 2 & 3.7 \\
Entrepreneur & 0 & 0 \\
Civil servants & 54 & 100 \\
\hline Total & & \\
\hline & & \\
\hline
\end{tabular}

The more age, the maturity level and strength of a person will be more mature in thinking and working and thus affecting the development and behavior of people or groups (Notoatmodjo, 2010).

The results of the study suggested that the characteristics of respondents who get family support are mostly aged $21-30$ years, with as many as 36 respondents $(66.7 \%)$. Mothers who are less than 30 years have complete immunization status than the rest. In the age range of 21-30 years, a person is still in a fertile and productive state. Also, the majority of mothers who are in this age range always follow the development of technology, this makes them more concerned about the health of their children, especially in providing complete 
primary immunization (Miftahol Hudhah, 2017).

Based on ethnicity, 29 respondents are Maduranese (53.7\%) and 25 Javanese $(46.3 \%)$. The results of this study are in line with the research of Izza that respondents' beliefs about immunization do not influence behavior willingness to immunize their children (Izza and Lestari, 2017). Madura and Javanese are in the area of the Sidotopo Community Health Center, where their homes are affordable with health services.

Based on Table 1, the majority of respondents took 12 years of education or high school/equivalent with the number of $26(48.1 \%)$. This result has a difference with research in the Gayam Health Centre at Sumenep, which states that the highest level of education is Junior High School/equivalent of 58\% (Miftahol Hudhah, 2017). Even though they have the same characteristics, these differences are probably caused by regional differences. Mothers who are highly educated will have high awareness, making it easier for someone to receive information, especially about complete primary immunizations. Also, it implies that the family has a concern about education so that mothers get support from the family to bring their children to the place of health services such as the Posyandu and the nearest public health center. Other studies state that the level of education influences the learning process. The higher the education, the more comfortable someone to receive information (Wardhani and Chotimah, 2018). On the other hand, someone with a higher level of education will think in a preventive direction, such as the imitation of her child. The education level provides a role to know the status of one's knowledge (Miftahol Hudhah, 2017).

Based on the occupation, the majority of respondents were housewives, namely 49 mothers (90\%). Many respondents were migrants, the location of the settlement was on the outskirts of the city near the Sunan Ampel pilgrimage, and the husband worked as a trader. It shows that mothers have much free time to take care of the family and can deliver their children for immunizations. Meanwhile, respondents who work as entrepreneurs are as many as five respondents $(10 \%)$. Based on interviews with working mothers, it is known that even though they are busy working, they always take the time to deliver their children for immunizations.

There is no relationship between maternal work and the achievement of complete primary immunizations. Mothers who work and non-working mothers have the same proportion of immunization (Hudhah, 2017).

\section{Family Support in Providing Complete Basic Immunization in the Sidotopo Public Health Center in Surabaya}

Vaccination is considered one of the most outstanding achievements of public health. Although there is evidence for the effectiveness of vaccines, their absorption rates are still far below the Centers for Disease Control and Prevention guidelines. The immunization decision-making process for parents is so complex and depends on related factors, knowledge, and experience (Espeleta et al., 2017).

The noncompliance of the general public with immunization can increase the number of cases of the disease that can be prevented by vaccination. Parents' views on the adverse effects of vaccination make many people prefer their children to be naturally infected by infectious diseases that can be prevented by immunization (Brooke, 2015; Rogers, 2018).

Table 2. Distribution Frequency based on Social Support

\begin{tabular}{lrr}
\hline \multicolumn{1}{c}{ Variables } & $\mathbf{n}$ & \multicolumn{1}{c}{$\%$} \\
\hline Emotional Support & & \\
\hline High & 34 & 63 \\
Medium & 19 & 35.2 \\
Low & 1 & 1.9 \\
\hline Appreciation Support & & \\
\hline High & 41 & 75.9 \\
Medium & 12 & 22.2 \\
Low & 1 & 1.9 \\
\hline InstrumentalSupport & & \\
\hline High & 34 & 63 \\
Medium & 20 & 37 \\
Low & 0 & 0 \\
\hline InformativeSupport & & \\
\hline High & 33 & 61.1 \\
Medium & 19 & 35.2 \\
Low & 2 & 2.7 \\
\hline Total & 54 & 100 \\
\hline
\end{tabular}

Noncompliance with immunization is a public health problem. The vaccine has been noted as one of the most- 
effective public health interventions against the spread of infectious diseases. However, there are increasing numbers of exceptions and doubts about non-medical vaccines. It has been linked to the fear of contracting a disease through vaccines and the general public's concerns about the safety of vaccines. Research showed that a reduction in vaccine coverage leads to a reduction of the effect of herd immunity, placing those who are not vaccinated or cannot be vaccinated at an increased risk of contracting preventable diseases. These factors lead to legislative actions, with some States implementing stricter exemption laws and more vigorous mandatory vaccine enforcement (Duclos and Bergevin, 2017; Rogers, 2018).

Complete basic immunization coverage in Surabaya in 2018, according to data from the Surabaya Health Office, has exceeded the target of $97.77 \%$. Health Centre, with the highest coverage, is Sidotopo $(96,51 \%)$ (Dinas Kesehatan Kota Surabaya, 2017).

From the results of research in the working area of the Sidotopo Health Centre in Surabaya, it can be seen that the majority of support provided by families in provided basic immunization consisted of emotional, appreciation, instrumental, and informative support is relatively high. Emotional support is social support provided by the family members with expressions of empathy, love, trust, care, and attention to the person concerned (Harnilawati, 2013). The emotional support provided by the family to mothers in the high category is $63 \%$. Emotional support from the family in the form of support to invite children to immunize, always remind the immunization schedule, besides listening to every complaint of the mother when worried when her child is sick due to immunization.

The family influences the formation of a way of behaving because family is the closest to a person. If the family does not give permission, then the implementation of immunization could not be done by the baby's mother because no support is provided by the mother (Sulistiyani, 2017).

Appreciation support is social support provided by the family through expressing positive appreciation for the person, encouragement to come forward, or agree with an individual's ideas or feelings. Appreciation support in this study was mostly high, at $75.9 \%$. This support is in the form of praise, the trust is given, and encouragement provided by the family to mothers to invite children to immunize. Mothers who get support in the way of encouragement and praise for their actions will be more motivated to take action (Sahar and Permatasari, 2016).

Instrumental support is social support provided by families involving the provision of direct assistance, such as providing financial assistance, goods, and as a support system for family members. Family members saw that the people who will be supportive, always ready to offer help and assistance if needed (Muhith and Siyoto, 2016).

Instrumental support was provided by $63 \%$. Indicated that family help care for children and provide financial assistance if the mother needs. It is consistent with research on family support relationships with the complete basic immunization, indicates that there are as many as $56.5 \%$ of women who get support instrumental in providing complete basic vaccination. Full family support is beneficial in giving a calm feeling to family members who have babies to be immunized (Rahayuningsih and Khairiah, 2019).

Informative support is social support provided by the family, including giving advice, hints, suggestions, or feedback that can be used by someone to overcome problems, especially in the provision of complete basic immunization (Harnilawati, 2013). The informative support provided is relatively high, at $61.1 \%$. This support is shown in the form of advice, direction, motivation, and information provided by the family to mothers related to immunization. According to previous research states that mothers who get information support from the family will increase the motivation of mothers to take action (Sahar and Permatasari, 2016)

Mothers who get information support from the family will increase their motivation to take action. The cause of research subjects did not provide complete basic immunization to their children is the lack of support from the environment for immunization, including from parents, husbands, friends, cadres. 
So there is no push for immunizations (Sulistiyani, 2017).

The family that provides good support is the reflection of a good functioning family. Family support cannot be separated from the family care function, where this function gives an essential role in the family. Family is a major supporting factor because it can maintain the health of other family members, so they are not susceptible to illness.

Table 3. Distribution of Complete Basic Immunization

\begin{tabular}{lrr}
\hline \multicolumn{1}{c}{ Variable } & Frequency & Percentage \\
\hline Complete & 37 & 68.5 \\
Incomplete & 17 & 31.5 \\
Total & 54 & 100 \\
\hline
\end{tabular}

The results of the data in Table 3 show that the distribution of complete basic immunization at the Sidotopo Health Centre in Surabaya is $37(68.5 \%)$, and incomplete basic immunization is 17 (31.5\%). Incomplete infant immunization status is also caused due to reasons at the time of the immunization schedule when the baby is ill, causing incompleteness in providing complete basic immunization. Also, based on interviews with cadres, it was found that in the Sidotopo Health Centre, the majority were migrants from Madura, with the majority of whom worked as traders in Sidotopo.

Table 4. Test Results of the influence of Family Support on Providing Immunizations

\begin{tabular}{lcr}
\hline \multicolumn{1}{c}{ Variable } & Sig & Exp (B) \\
\hline Emotional Support & 0.015 & 4.463 \\
Appreciation Support & 0.455 & 1.773 \\
Instrumental Support & 0.088 & 0.286 \\
Informative Support & 0.128 & 0.296 \\
\hline
\end{tabular}

The results of the data in Table 4 show that the dependent variable in this study is the complete basic immunization. In contrast, the independent variables in this study are family support consisting of emotional, appreciation, instrumental, and informative support. After a logistic regression test, the results showed that the variables that influence in giving complete basic immunization are emotional support that is sig. $=0.015$, with $\operatorname{Exp}(B)=4.463$. It can be concluded that respondents who get emotional support from their family are 4.463 times more likely to provide complete basic immunization compared to mothers who do not get emotional support. On the other hand, appreciation, instrumental, and informative support did not affect giving immunization.

The results of the study show that although the support provided by the family is high, it does not affect the provision of immunization. Based on the results of interviews conducted, the completeness of the provision of immunizations in the area of the Sidotopo Health Centre is not only from the role of family support. However, there is the role of public health workers and community leaders who participate. Moreover, incomplete infant immunization status is also caused due to reasons at the time of the immunization schedule when the baby is ill, causing incompleteness in providing complete basic immunization. Also, based on interviews with cadres, it was found that in the Sidotopo Health Centre, the majority were migrants from Madura, with the majority of whom worked as traders in Sidotopo and were sedentary or nomads, which makes it difficult to know how the baby's immunization status.

Support is obtained not only from the family. It is also obtained from the outside environment in the form of health cadres, health workers, the influence of public service advertisements in printed media, such as posters and leaflets as well as electronic media such as radio and television (Sahar and Permatasari, 2016). According to previous research, there is a relationship between the communication of health workers with basic immunization status in infants. Providing good communication to mothers can influence the decision of mothers in providing basic immunizations (Arumsari, 2015). Moreover, parents are not an inhibiting factor in giving immunizations, but the incompleteness of immunization can be caused by the child's problems and family problems. There are no difficulties/obstacles in getting immunizations in children with complete or incomplete immunization status (Triana, 2016).

The results of this study indicate that family support has a significant role in supporting maternal behavior in providing complete basic immunization. Also, based on the results of the analysis, social support obtained by mothers in 
providing immunizations is not only from family support but also from outside environments such as neighbors, cadres, health workers, and the media.

\section{CONCLUSION}

The provision of complete primary immunizations is categorized as having high family support, which includes emotional support, appreciation support, instrumental support, and informative support. Even though the number of family support is high, emotional support is a significant influence in providing immunization. Therefore, appreciation support, instrumental support, and informative support did not significantly affect immunization.

The completeness of immunization in the Sidotopo Health Centre is also influenced by reinforcing factors such as community leaders or cadres in the area. They often reprimand and invite mothers to provide complete basic immunizations for their babies. Moreover, another critical factor is the health workers that often carry out socialization about immunization to the community in Sidotopo Health Centre in Surabaya.

\section{REFERENCE}

Arumsari, D. R. (2015) 'Faktor-Faktor yang Berhubungan dengan Status Imunisasi Dasar Pada Bayi', Jurnal Pendidikan Kesehatan, 4(1), pp. 9-15.

Brooke, D. (2015) 'Lebanese Muslim Immigrants in Australia', 10(3), pp. 229-236.

Dinas Kesehatan Kota Surabaya (2017) 'Profil Kesehatan Kota Surabaya 2017'.

Duclos, P. and Bergevin, Y. (2017) 'Immunization safety: A global priority - a major contribution of Canada's international immunization efforts', Paediatrics \& Child Health, 5(7), pp. 374-376. doi: 10.1093/pch/5.7.374.

Dumilah, R. (2016) 'HUBUNGAN ANTARA DUKUNGAN TENAGA KESEHATAN DENGAN STATUS IMUNISASI DASAR PADA BAYI USIA 1-2 TAHUN DI DESA TANJUNGPURA KABUPATEN', MMUT, 7(2), p. 2016.

Espeleta, H. C. et al. (2017) 'Immunizing Children: A Qualitative Analysis of
Future Parental Decision Making', Clinical Pediatrics, 56(11), pp. 10321039. doi: 10.1177/0009922817701173.

Harnilawati (2013) Konsep dan Proses Keperawatan Keluarga. Takalar Sulsel: Pustaka As Salam.

Izza, N. and Lestari, D. (2017) 'FAKTOR ORANG TUA DAN STATUS IMUNISASI DPT Factor of Parents and DPT Immunization Status in Ketapang and Sokobanah Sub District , Sampang District', (17), pp. 43-51.

Kementerian Kesehatan Republik Indonesia (2018) Profile Kesehatan Indonesia Tahun 2017, Kementerian Kesehatan Republik Indonesia. Jakarta. doi: 10.1002/qj.

Majelis Ulama Indonesia (2016) 'Fatwa Majelis Ulama Indonesia (MUI) tentang imunisasi', Mui.

Marmot, M. and Wilkinson, R. (2012) 'Social Determinants of Health Social Determinants of Health', New York: Oxford University press, pp. 20132014. doi: 10.1001/jama.2016.17335.

Miftahol Hudhah, A. C. H. (2017) 'Di Puskesmas Gayam Kabupaten Sumenep Mother' S Behavior in Complete Basic Immunization At', Di Puskesmas Gayam Kabupaten Sumenep Mother' S Behavior in Complete Basic Immunization At, pp. 167-180.

Muhith, A. and Siyoto, S. (2016) Pendidikan Keperawatan Gerontik. 1st edn. Yogyakarta: CV Andi Offset.

Notoatmodjo, S. (2010) Ilmu Perilaku Kesehatan. Jakarta: Rineka Cipta.

Rahayuningsih, I. and Khairiah (2019) 'Hubungan Dukungan Keluarga dengan Pemberian Imunisasi Dasar pada Bayi di Desa Gue Gajah, Aceh Besar', Jurnal Kesehatan Cehadum, 1(1), pp. 39-49.

Rogers, K. M. (2018) 'Immunization Noncompliance: Gauging the Cause, Effect, and Management in the School Setting', NASN School Nurse, p. $1942602 \times 1879986$. doi: 10.1177/1942602x18799868.

Sahar, J. and Permatasari, H. (2016) 'Dukungan keluarga terhadap pemberian asi eksklusif pada bayi di kota jambi', jmj, 1, pp. 76-86.

Sulistiyani, P. (2017) 'Gambaran Penolakan Masyarakat terhadap Imunisasi Dasar Lengkap bagi Balita', Jurnal Kesehatan Masyarakat, 5(5), 
pp. 1081-1091.

Triana, V. (2016) 'Panduan lengkap kesehatan mengenal,mencegah \& mengobati penularan Penyakit dari infeksi', pp. 123-135. doi: 10.24893/jkma.10.2.123-135.2016.

Undang-Undang Republik Indonesia Nomor 36 Tahun 2009 tentang Kesehatan
(2009). Indonesia.

Wardhani, S. K. and Chotimah, C. (2018) 'Hubungan Dukungan Suami Dengan Keberhasilan Inisiasi Menyusu Dini Pada Ibu Bersalin Di Klinik Bersalin Bu Nafsi Wonogiri', indonesian journal on medical science, 5(2), pp. 134-140. 